\title{
Protective effect of dietary long-chain $n-3$ polyunsaturated fatty acids on bone loss in gonad-intact middle-aged male rats
}

\author{
Chwan-Li Shen ${ }^{1}$, James K. Yeh ${ }^{2}$, Jahan Rasty ${ }^{3}$, Yong $\mathrm{Li}^{4}$ and Bruce A. Watkins ${ }^{4}$ \\ ${ }^{1}$ Department of Pathology, Texas Tech University Health Sciences Center, Lubbock, TX, USA \\ ${ }^{2}$ Bone Metabolism Laboratory, Winthrop-University Hospital, Mineola, NY, USA \\ ${ }^{3}$ Department of Mechanical Engineering, Texas Tech University, Lubbock, TX, USA \\ ${ }^{4}$ Center for Enhancing Foods to Protect Health, Lipid Chemistry and Molecular Biology Laboratory, Purdue University, West Lafayette, \\ IN, USA \\ (Received 26 May 2005 - Revised 2 November 2005 - Accepted 8 November 2005)
}

\begin{abstract}
This study evaluated the effect of a fat blend containing long-chain (LC) $n$-3 PUFA on bone mineral density (BMD) and bone metabolism in gonad-intact middle-aged male rats (12 months old, $n$ 28). Seven rats were killed on day 0 of dietary intervention to determine the baseline BMD. The remaining rats (seven per group) were fed a diet with one of the following dietary lipid treatments ( $\mathrm{g} / \mathrm{kg}$ diet): $167 \mathrm{~g}$ safflower oil $+33 \mathrm{~g}$ menhaden oil (N6 + N3 diet, control), $200 \mathrm{~g}$ safflower oil (N6 diet, almost devoid of LC $n-3$ PUFA), or $190 \mathrm{~g}$ menhaden oil $+10 \mathrm{~g}$ corn oil (N3 diet, rich in LC $n-3$ PUFA) for 20 weeks. After 20 weeks, all dietary treatment groups had a lower BMD compared with the baseline reference. However, rats fed the N3 diet had the highest bone mineral content and cortical + subcortical BMD compared with those fed the N6 and control N6 + N3 diet. Compared with the control (N6 + N3) group, rats fed the N3 diet had higher values for serum insulin-like growth factor-I, parathyroid hormone, $1,25-(\mathrm{OH})_{2}$ vitamin $\mathrm{D}_{3}$ and bone-specific alkaline phosphatase activity, but lower bone NO production and urinary $\mathrm{Ca}$, whereas rats fed the N6 diet had higher bone prostaglandin $\mathrm{E}_{2}$ production and serum pyridinoline. These findings indicate a protective action of LC $n$-3 PUFA on ageing-induced bone loss in gonad-intact middle-aged male rats through a modulation of local factors and systemic calcitrophic hormones.
\end{abstract}

Menhaden oil: $n$-3 PUFA: Bone metabolism: Gonad-intact middle-aged male rats

Although women have been the main focus for research on osteoporosis, emerging evidence indicates that ageing-induced osteoporosis is a common occurrence in men (Rowe \& Kahn, 1987). The mechanism for ageing-induced bone loss in middleaged and elderly men is not well understood (Center et al. 1999). Some postulate that there is an imbalance between bone formation and bone resorption apparently regulated by bonederived local factors such as prostaglandins (Mundy, 2003), NO (Ralston et al. 1995) and cytokines (Mundy, 2003; Raisz \& Rodan, 2003) and systemic hormones such as insulin-like growth factors (IGF), parathyroid hormone and vitamin D (Mundy 2003; Raisz \& Rodan, 2003). A logical approach is therefore to investigate changes in both local factors and systemic hormones associated with the development of osteoporosis.

High-fat diets are pervasive in Western cultures (Rizek et al. 1983), and when this is coupled with elevated risk of chronic disease caused by ageing, it is reasonable to speculate that the source of dietary fat could be a contributory lifestyle factor associated with osteoporosis and age-related bone loss in men (Hou et al. 1990). When considering sources of fat, a body of scientific evidence based on results in cell cultures (Watkins et al. 2003), animals (Sakaguchi et al. 1994; Kruger et al. 1996; Schlemmer et al. 1999; Sun et al. 2003; Watkins et al. 2003, 2005) and human subjects (Kruger et al. 1998) indicates that long-chain (LC) n-3 PUFA may protect skeletal health and potentially improve conditions associated with male osteoporosis. However, all animal studies employed a moderate fat level in the experimental diets, with an oestrogen-deficiency bone loss model in female rodents. No study has evaluated the effect of a high-fat diet rich in EPA (20:5n-3), docosapentaenoic acid (22:5n-3) and DHA (22:6n-3) on bone metabolism and bone mass during male ageing. Therefore, in this study, we investigated the effect of menhaden oil (rich in EPA, docosapentaenoic acid and DHA) as part of a high-fat diet on bone metabolism and bone mineral density (BMD) in gonad-intact middle-aged male rats. Based on the protective effect of LC $n-3$ PUFA against bone loss in ovariectomized female rats (Sakaguchi et al. 1994; Kruger et al. 1996; Schlemmer et al. 1999; Watkins et al. 2003, 2005) and mice (Sun et al. 2003), we hypothesized that ageing-induced bone loss in gonad-intact male rats would be minimized with LC $n-3$ PUFA. We further hypothesized that such an effect of LC $n$-3 PUFA on bone loss would be due to the modulation of local and systemic factors that regulated bone metabolism. 
Forty per cent of the energy intake of the experimental diet was provided by the dietary fat source $(20 \% \mathrm{w} / \mathrm{w})$ in this study. This design incorporates the high-fat diet that is pervasive in Western cultures and represents an important risk factor for the prevalence of chronic diseases, including osteoporosis, during male ageing (Kopelman, 2000). Similar dietary fat levels have been used in experimental rodent diets (Vaskonen et al. 1996; Choi et al. 2004; Bhattacharya et al. 2005). The male aged rat was selected because (1) men do not normally experience an abrupt loss of sex hormones, as occurs in women following the menopause, and (2) the middleaged male rat has completed its bone growth and commenced bone loss (Wang et al. 2001). Studying the effects of LC $n-3$ PUFA on bone remodelling in middle-aged male rats will advance our understanding of their effects on skeletal biology in terms of minimizing bone loss in elderly men.

\section{Materials and methods}

\section{Preparation of rat diets}

All rats were maintained on the NIH-31 diet (Nadon, 2004) at the animal laboratory facilities before being shipped to our laboratory. Upon arrival, rats were assigned to dietary treatment groups and fed a semi-purified basal diet (modified AIN-93 diet; Dyets, Bethlehem,
PA, USA) supplemented with one of the following lipid treatments $(\mathrm{g} / \mathrm{kg}$ diet): $167 \mathrm{~g}$ safflower oil $+33 \mathrm{~g}$ menhaden oil (control $\mathrm{N} 6+\mathrm{N} 3$ diet containing 6.1\% w/w LC $n-3$ PUFA), $200 \mathrm{~g}$ safflower oil (N6 diet; almost devoid of LC $n-3$ PUFA, containing only $0.3 \%$ w/w LC $n$-3 PUFA) or $190 \mathrm{~g}$ menhaden oil $+10 \mathrm{~g}$ corn oil (N3 diet; rich in LC $n-3$ PUFA, containing $35 \%$ w/w LC $n-3$ PUFA). The fatty acid and ingredient compositions of the diets are shown in Table 1. The $n-6: n-3$ PUFA ratio in the N6, N6 + N3 and N3 diets was 242, $10 \cdot 0$ and $0 \cdot 16$, respectively. The N6 $+\mathrm{N} 3$ diet was the control diet because it contained adequate levels of essential PUFA and the $n-6: n-3$ PUFA ratio was 10:1, as recommended for human dietary intake (Simopoulos et al. 1999; Watkins et al. 2000) and within the range found in Western diet. Compared with the control N6 + N3 diet, the N6 diet was almost devoid of LC $n-3$ PUFA, whereas the N3 diet contained a higher level of $n-3$ LC PUFA. In order to prevent essential fatty acid deficiency, $1 \%$ corn oil was added to the N3 diet. All diets were isocaloric and isonitrogenous. Fresh diets were prepared every $14 \mathrm{~d}$ and kept at $-20^{\circ} \mathrm{C}$ until fed to the rats.

\section{Experimental design}

Twenty-eight male F344 $\times$ BNF1 rats $(12$ months old, average weight $492 \pm 15.6 \mathrm{~g}$ ), obtained from the National Institute on Aging, Bethesda, MD, USA, were randomized into four groups

Table 1. Fatty acid and ingredient composition of the NIH-31 diet and dietary treatments

\begin{tabular}{|c|c|c|c|c|}
\hline \multirow[b]{2}{*}{ Fatty acid } & \multirow[b]{2}{*}{$\begin{array}{l}\text { NIH-31† } \\
\text { Mean }\end{array}$} & \multicolumn{3}{|c|}{ Dietary treatment $\ddagger \S$} \\
\hline & & $\begin{array}{c}\mathrm{N} 6+\mathrm{N} 3 \text { diet } \\
\text { Mean }\end{array}$ & $\begin{array}{l}\text { N6 diet } \\
\text { Mean }\end{array}$ & $\begin{array}{l}\text { N3 diet } \\
\text { Mean }\end{array}$ \\
\hline & & \multicolumn{3}{|c|}{$\mathrm{g} / 100 \mathrm{~g}$ total fatty acids } \\
\hline $14: 0$ (myristic) & 0.62 & $1 \cdot 24$ & 0.15 & $6 \cdot 70$ \\
\hline $16: 0$ (palmitic) & $14 \cdot 48$ & $8 \cdot 24$ & $6 \cdot 41$ & $17 \cdot 38$ \\
\hline $16: 1 n-7$ (palmitoleic) & 1.34 & 0.08 & 0.09 & ND \\
\hline $18: 0$ (stearic) & 3.42 & 2.56 & 2.39 & $3 \cdot 39$ \\
\hline $18: 1 n-9$ (oleic) & $25 \cdot 06$ & $14 \cdot 80$ & $15 \cdot 93$ & $9 \cdot 18$ \\
\hline 18: 1n-7 (vaccenic) & $1 \cdot 37$ & 1.05 & 0.64 & 3.09 \\
\hline $18: 2 n-6$ (linoleic) & $45 \cdot 80$ & $61 \cdot 23$ & $72 \cdot 61$ & $4 \cdot 27$ \\
\hline $18: 3 n-3(\alpha$-linolenic) & $4 \cdot 27$ & 0.38 & 0.16 & 1.48 \\
\hline $18: 4 n-3$ (stearidonic) & ND & 0.54 & ND & 3.19 \\
\hline $20: 1 n-9$ (gondoic) & 0.61 & 0.45 & 0.28 & $1 \cdot 29$ \\
\hline $20: 4 n-6$ (arachidonic) & 0.26 & 0.14 & ND & 0.83 \\
\hline $20: 5 n-3$ (EPA) & ND & $2 \cdot 09$ & ND & 12.57 \\
\hline $22: 5 n-3$ (docosapentaenoic) & 0.22 & 0.42 & ND & 2.51 \\
\hline $22: 6 n-3(\mathrm{DHA})$ & 0.94 & 2.67 & 0.14 & $15 \cdot 28$ \\
\hline SAT & $19 \cdot 37$ & $12 \cdot 84$ & 9.63 & $28 \cdot 81$ \\
\hline Total MUFA & $28 \cdot 66$ & $18 \cdot 33$ & $17 \cdot 35$ & $23 \cdot 16$ \\
\hline Total PUFA & 51.94 & 67.60 & 72.91 & $40 \cdot 83$ \\
\hline$n-6$ PUFA & 46.51 & 61.50 & $72 \cdot 61$ & $5 \cdot 80$ \\
\hline$n-3$ PUFA & 5.43 & $6 \cdot 10$ & 0.30 & 35.03 \\
\hline$n-6: n-3$ PUFA & 8.57 & $10 \cdot 09$ & 242 & 0.16 \\
\hline
\end{tabular}

SAT, total saturated fatty acids; ND, not detected.

† All rats were maintained on $\mathrm{NIH}-31$ diet at the animal laboratory facilities before being shipped to our laboratory. The NIH-31 diet contained the following (g/kg diet): protein, 184.20; fat, 44.7; fibre, 40.5; ash, 66.4; nitrogenfree extract, 559.1; moisture, 105.1.

¥The semi-purified basal diet (modified AIN-93 diet) for experimental diets contained the following ( $\mathrm{g} / \mathrm{kg}$ diet) casein, 200.00; L-cystine, 3.00; sucrose, 100.00; cornstarch, 292.48; DYETROSE, 107.00; oil, 200.00; cellulose, 50.00; mineral mix, 35.00; vitamin mix, 10.00; choline bitartrate, 2.50; tert-Buthlhydroquinone, 0.02 The mineral mix contained (mg/kg diet): $\mathrm{CaCO}_{3}, 12495 \cdot 00 ; \mathrm{K}_{2} \mathrm{HPO}_{4}, 6860 \cdot 00 ; \mathrm{C}_{6} \mathrm{H}_{5} \mathrm{O}_{7} \mathrm{~K}_{3} \cdot \mathrm{H}_{2} \mathrm{O}, 2477.00 ; \mathrm{NaCl}$ 2590.00; $\mathrm{K}_{2} \mathrm{SO}_{4}, 1631.00 ; \mathrm{MgO}, 840 \cdot 00 ; \mathrm{C}_{6} \mathrm{H}_{5} \mathrm{O}_{7} \mathrm{Fe}$ USP, 212.10; $\mathrm{ZnCO}_{3}, 57.75 ; \mathrm{MnCO}_{3}, 22.05 ; \mathrm{CuCO}_{3}$ 10.50; $\mathrm{KIO}_{3}, 0.35 ; \mathrm{Na}_{2} \mathrm{SeO}_{4}, 0.369 ;\left(\mathrm{NH}_{4}\right)_{2} \mathrm{MoO}_{4} \cdot \mathrm{H}_{2} \mathrm{O}, 0.278 ; \mathrm{Na}_{2} \mathrm{O}_{3} \mathrm{Si} \cdot 9 \mathrm{H}_{2} \mathrm{O}, 50.75 ; \mathrm{CrK}\left(\mathrm{SO}_{4}\right)_{2} \cdot 12 \mathrm{H}_{2} \mathrm{O} .9 .625$ $\mathrm{LiCl}, 0.609 ; \mathrm{H}_{3} \mathrm{BO}_{3}, 2.853 ; \mathrm{NaF}, 2.223 ; \mathrm{NiCO}_{3}, 1.113 ; \mathrm{NH}_{4} \mathrm{VO}_{3}, 0.231$. The vitamin mix contained (mg $/ \mathrm{kg}$ diet): thiamine $\mathrm{HCl}, 6.00$; riboflavin, 6.00 ; pyridoxine $\mathrm{HCl}, 7.00$; niacin, 30.00; calcium pantothenate, 16.00 ; folic acid 2.00; biotin, 0.20; cyanocobalamine (B-12) (0.1\%), 25.00; all-trans-retinyl palmitate (500, $000 \mathrm{IU} / \mathrm{g}), 8.00$; allrac- $\alpha$-tocopheral acetate $(500 \mathrm{IU} / \mathrm{g}), 25.00$; cholecalciferol $(400,000 \mathrm{IU} / \mathrm{g}), 2.50$; phylloquinone, 0.75 .

$\S$ Dietary lipid contents (per kg): safflower oil $167 \mathrm{~g}+$ menhaden oil $33 \mathrm{~g}(\mathrm{~N} 6+\mathrm{N} 3$ diet); safflower oil $200 \mathrm{~g}$ (N6 diet); menhaden oil $190 \mathrm{~g}+$ corn oil $10 \mathrm{~g}$ (N3 diet). 
of seven rats each. The rats were assigned to the baseline and three dietary treatment $(\mathrm{N} 6+\mathrm{N} 3, \mathrm{~N} 6, \mathrm{~N} 3)$ groups. Rats in the baseline group were killed on day 0 of dietary intervention, and serum and bone samples were collected for later analysis. Values from the baseline group were compared with the results obtained at the end of the 20-week feeding period to determine any age effect on the parameters being studied. Rats in each dietary treatment group were fed their respective diets for 20 weeks. Rats were housed individually under a controlled temperature of $21 \pm 2^{\circ} \mathrm{C}$ with a $12 \mathrm{~h}$ light-dark cycle. Feed and distilled water were provided at libitum. Rats were weighed every other week and examined daily. All procedures were approved by the Texas Tech University Health Sciences Center Institutional Animal Care and Use Committee.

Prior to the rats being killed, $72 \mathrm{~h}$ urine samples were collected from each animal and stored at $-20^{\circ} \mathrm{C}$ until analysed. All animals were anaesthetized with sodium pentobarbital $(50 \mathrm{mg} / \mathrm{kg}$ intraperitoneally). Blood samples were drawn from the heart into Vacutainer tubes (BD, Franklin Lakes, NJ, USA), serum being isolated and immediately stored at $-80^{\circ} \mathrm{C}$ for biochemical analysis. Final body weights were recorded, and the femora, tibias and humeri were harvested and cleaned of adhering soft tissue. The left tibial samples were kept on ice at the time of collection and then frozen at $-80^{\circ} \mathrm{C}$ for fatty acid analysis. The right humeri were processed for determination of ex vivo prostaglandin $\mathrm{E}_{2}$ $\left(\mathrm{PGE}_{2}\right)$ and $\mathrm{NO}$ production (see later). The left femur samples were preserved in $70 \% \mathrm{v} / \mathrm{v}$ ethanol for determination of BMD.

\section{Analysis of fatty acid composition}

Lipids in the diets and bone samples were extracted as described previously (Watkins et al. 1996). Fatty acid concentrations in the diets and bones were measured using a gas chromatograph, and data were expressed as the area percentage of fatty acid methyl esters in the lipids, as previously described (Watkins et al. 2000).

\section{Ex vivo production of prostaglandin $E_{2}$ and $N O$}

Ex vivo $\mathrm{PGE}_{2}$ production in bone organ cultures was performed as described by Watkins et al. (2000). $\mathrm{PGE}_{2}$ and NO concentrations in the bone organ culture medium were measured by RIA and Griess assay, respectively, as described by Shen et al. (2004). $\mathrm{PGE}_{2}$ and $\mathrm{NO}$ values were expressed as nanograms and nanomoles per gram of dry bone weight, respectively.

Serum insulin-like growth factor-I, parathyroid hormone, 25-OH vitamin $\mathrm{D}_{2}$ and 1,25-( $\left.\mathrm{OH}\right)_{2}$ vitamin $\mathrm{D}_{3}$ levels

Serum IGF-I concentration was measured using the IGF-I (Direct) RIA kit (ALPCO Diagnostics, Windham, NH, USA). Serum parathyroid hormone $(\mathrm{PTH})$ concentration was measured using the rat bioactive intact PTH ELISA kit (ALPCO Diagnostics). The intraand interassay CV for PTH were 9.4 and $4.3 \%$, respectively. Concentrations of $25-\mathrm{OH}$ vitamin $\mathrm{D}_{2}$ and $1,25-(\mathrm{OH})_{2}$ vitamin $\mathrm{D}_{3}$ in serum were measured using a radioreceptor-binding ELISA (DiaSorin Inc. Stillwater, MN, USA). The intra- and interassay CV for $25-\mathrm{OH}$ vitamin $\mathrm{D}_{2}$ were 7.0 and $4.1 \%$, and for $1,25-(\mathrm{OH})_{2}$ vita$\min \mathrm{D}_{3}$ were 17.3 and $8.5 \%$, respectively.
Serum bone-specific alkaline phosphatase, pyridinoline, Ca and phosphate levels

Serum bone-specific alkaline phosphatase (BALP) activity was measured using a semi-automated quantitative assay as previously described (Hoffmann et al. 1994). The concentration of serum pyridinoline (PYD), a product of the breakdown of bone and cartilage collagen, was measured using the Metra Serum PYD ELISA (Quidel, San Diego, CA, USA). The intra- and interassay CV for PYD were 8.3 and $8.7 \%$, respectively. Serum and urinary $\mathrm{Ca}$, inorganic phosphate $(\mathrm{Pi})$ and creatinine concentrations were measured by an automated clinical chemistry analyser (Model RxL; Dade Behring, Deerfield, IL, USA). Data for urinary $\mathrm{Ca}$ and $\mathrm{Pi}$ concentrations were expressed as $\mathrm{mg} / \mathrm{mg}$ creatinine.

\section{Bone mineral density}

The total bone area, bone mineral content (BMC) and BMD of the whole left femur of each rat were determined by dual-energy X-ray absorptiometry (DEXA; HOLOGIC QDR-2000 plus DEXA; Hologic Inc., Waltham, MA, USA). The machine was set at an ultra-high-resolution mode with a line spacing of $0.0254 \mathrm{~cm}$, a resolution of $0.0127 \mathrm{~cm}$ and a collimator diameter of $0.9 \mathrm{~cm}$. The total, trabecular, cortical, and subcortical regions of the excised metaphyseal distal femurs of rats were also scanned by a peripheral quantitative computerized tomography X-ray machine (STRATEC XCT-960, Norland Medical Systems, Fort Atkinson, WI, USA).

\section{Statistical analysis}

Data are presented as means with their standard errors. All data were analysed with SigmaStat software (version 2.03; Systat Software Inc., Richmond, CA, USA). Differences between baseline and each dietary treatment group were analysed by student's $t$ test to determine age effect $(\alpha=0 \cdot 05)$. The differences between the three dietary treatment groups (N6 + N3, N6, N3) were analysed by one-way ANOVA followed by Tukey's test to determine the effect of fat type $(\alpha=0.05)$.

\section{Results}

\section{Diet and bone fatty acid analysis}

Body weight and food consumption were not affected by the dietary treatments. The $n-6: n-3$ PUFA ratio was calculated from the analysed fatty acid values of the formulated dietary treatments (Table 1). The $n-6: n-3$ PUFA ratio ranged from $0 \cdot 16$ to 242 . The N6 diet had the highest ratio (242) and contained $72.61 \mathrm{~g}$ of $18: 2 n$ -6 (linoleic acid) per $100 \mathrm{~g}$ total fatty acids. The N3 diet had the lowest ratio $(0 \cdot 16)$ and contained $12.6 \mathrm{~g}$ EPA, $2.51 \mathrm{~g}$ docosapentaenoic acid and $15 \cdot 3 \mathrm{~g}$ DHA per $100 \mathrm{~g}$ total fatty acids.

The fatty acid composition of the cortical bone of middle-aged male rats was significantly influenced by the dietary PUFA treatment compared with the baseline group (Table 2). Significant differences in fatty acid profiles were also observed between the treatment groups. Relative to the control N6 $+\mathrm{N} 3$ group, rats fed the N6 diet (almost devoid of LC $n$-3 PUFA) had higher values for $18: 2 n-6,20: 4 n-6$, total PUFA and total $n-6$ PUFA, but lower values for $14: 0,16: 0,18: 1 n-7,20: 5 n-3,22: 5 n-3$, $22: 6 n-3$, total saturated fatty acids and total $n-3$ PUFA in cortical bone. In contrast, rats fed the N3 diet (high in LC $n-3$ PUFA) had 
Table 2. Fatty acid composition in cortical bone of gonad-intact middle-aged male rats

(Mean values with their standard errors, $n 7$ )

\begin{tabular}{|c|c|c|c|c|c|c|c|c|}
\hline \multirow[b]{3}{*}{ Fatty acid } & & & \multicolumn{6}{|c|}{ Dietary treatment $†$} \\
\hline & \multicolumn{2}{|c|}{ Baseline } & \multicolumn{2}{|c|}{$\mathrm{N} 6+\mathrm{N} 3$} & \multicolumn{2}{|c|}{ N6 } & \multicolumn{2}{|c|}{ N3 } \\
\hline & Mean & SEM & Mean & SEM & Mean & SEM & Mean & SEM \\
\hline & & & \multicolumn{6}{|c|}{$\mathrm{g} / 100 \mathrm{~g}$ total fatty acids } \\
\hline $14: 0$ (myristic) & 1.04 & 0.003 & 1.40 & $0.02^{b *}$ & 0.70 & $0.01^{\mathrm{c} *}$ & 3.67 & $0.09 \dagger^{a *}$ \\
\hline $16: 0$ (palmitic) & $19 \cdot 7$ & 0.002 & $16 \cdot 90$ & $0 \cdot 16^{\mathrm{b} *}$ & $14 \cdot 2$ & $0.27^{\mathrm{c} *}$ & 23.03 & $0.50^{a *}$ \\
\hline $16: 1 n-7$ (palmitoleic) & $1 \cdot 72$ & 0.003 & 1.93 & $0 \cdot 27^{\mathrm{b}}$ & 1.08 & $0.07^{\mathrm{b}}$ & $6 \cdot 12$ & $0.39^{a *}$ \\
\hline $18: 0$ (stearic) & $5 \cdot 86$ & 0.01 & $4 \cdot 88$ & $0 \cdot 15^{\star}$ & $4 \cdot 78$ & $0 \cdot 10^{\star}$ & $5 \cdot 48$ & 0.29 \\
\hline 18: $1 n-9$ (oleic) & $22 \cdot 3$ & 0.15 & $17 \cdot 7$ & $0 \cdot 32^{*}$ & $18 \cdot 3$ & $0 \cdot 16^{\star}$ & $18 \cdot 21$ & $0.44^{*}$ \\
\hline 18: 1n-7 (vaccenic) & 0.77 & 0.21 & 3.12 & $0.06^{\mathrm{b} *}$ & 2.57 & $0.07^{\mathrm{C} *}$ & $4 \cdot 86$ & $0.07^{\mathrm{a}}$ \\
\hline $18: 2 n-6$ (linoleic) & $32 \cdot 77$ & 0.06 & 41.98 & $0.77^{\mathrm{b} *}$ & $49 \cdot 89$ & $0.46^{\mathrm{a} *}$ & $15 \cdot 43$ & $0.59^{\mathrm{c} *}$ \\
\hline $20: 4 n-6$ (arachidonic) & 2.64 & 0.01 & 1.54 & $0.04^{b *}$ & 2.44 & $0.40^{\mathrm{a}}$ & 1.57 & $0.09 \dagger^{\mathrm{b} *}$ \\
\hline $20: 5 n-3$ (eicosapentaenoic) & $0 \cdot 14$ & 0.07 & 0.52 & $0.02^{b *}$ & 0.02 & $0.01^{\mathrm{c}}$ & $2 \cdot 32$ & $0 \cdot 16^{\mathrm{a} *}$ \\
\hline $22: 5 n-3$ (docosapentaenoic) & $1 \cdot 20$ & 0.03 & $1 \cdot 28$ & $0.04^{\mathrm{b}}$ & 0.20 & $0.02^{\mathrm{C} *}$ & $2 \cdot 47$ & $0.07^{a *}$ \\
\hline 22:6n-3 (docosahexaenoic) & $1 \cdot 20$ & 0.07 & 2.76 & $0 \cdot 12^{b *}$ & 0.42 & $0.04^{\mathrm{c} *}$ & 8.58 & $0 \cdot 23^{a *}$ \\
\hline SAT & $27 \cdot 52$ & 0.38 & $23 \cdot 88$ & $0 \cdot 30^{\mathrm{b} *}$ & $20 \cdot 38$ & $0.38^{\mathrm{C} *}$ & $33 \cdot 26$ & $0 \cdot 84^{a *}$ \\
\hline Total MUFA & $29 \cdot 61$ & 0.34 & 23.52 & $0.50^{\mathrm{b} *}$ & $22 \cdot 60$ & $0 \cdot 24^{\mathrm{b} *}$ & $30 \cdot 11$ & $0 \cdot 81^{a}$ \\
\hline Total PUFA & $41 \cdot 30$ & 0.20 & $49 \cdot 85$ & $0.56^{\mathrm{b} *}$ & $56 \cdot 05$ & $0.27^{\mathrm{a} *}$ & 32.49 & $0 \cdot 31^{\mathrm{c} *}$ \\
\hline$n-6$ PUFA & $37 \cdot 72$ & 0.20 & $45 \cdot 06$ & $0.58^{\mathrm{b} *}$ & $55 \cdot 25$ & $0.30^{\mathrm{a} *}$ & $18 \cdot 25$ & $0.58^{\mathrm{C} *}$ \\
\hline$n-3$ PUFA & 3.58 & 0.10 & 4.87 & $0 \cdot 16^{\mathrm{b} *}$ & 0.80 & $0.07 \dagger^{\mathrm{c}}$ & $14 \cdot 28$ & $0.44^{a *}$ \\
\hline$n-6: n-3$ PUFA & 10.58 & 0.28 & $9 \cdot 31$ & $0.34^{\mathrm{b}}$ & $72 \cdot 48$ & $7 \cdot 84^{a *}$ & $1 \cdot 29$ & $0.08^{\mathrm{C} *}$ \\
\hline
\end{tabular}

N6 + N3, safflower oil + menhaden oil diet; N6, safflower oil diet; N3, menhaden oil diet; SAT, total saturated fatty acids.

${ }^{a, b, c}$ Mean values within a row with unlike superscript letters differ significantly between three dietary treatments by one-way ANOVA followed by Tukey's test $(P<0.05)$.

${ }^{*}$ Mean values within a row indicated the difference between baseline group and dietary treatment groups by Student's $t$ test $(P<0.05)$.

†For details of diets, see Table 1.

higher values for $14: 0,16: 0,16: 1 n-7,18: 1 n-7,20: 5 n-3,22: 5 n-3$, $22: 6 n-3$, total saturated fatty acids, total MUFA and total $n-3$ PUFA, but lower values for 18:2n-6 and total $n-6$ PUFA in cortical bone compared with those fed the control diet (N6 + N3 diet).

\section{Local factors and systemic calcitrophic hormones}

Compared with the baseline group: the N6 + N3 group had a lower value for $\mathrm{PGE}_{2}$ production but no difference in NO production and serum IGF-I concentration; the N6 group showed no difference in $\mathrm{PGE}_{2}$, NO or IGF-I; the N3 group had lower levels of $\mathrm{PGE}_{2}$ and $\mathrm{NO}$ production, but a higher value for serum IGF-I concentration (Table 3). Compared with the rats fed the control N6 + N3 diet, rats fed the N6 diet had a significantly higher $\mathrm{PGE}_{2}$ level, whereas those fed the N3 diet had lower NO production in bone culture but higher IGF-I concentration in serum.

Compared with the baseline group, all dietary treatment groups had significantly higher concentrations of calcitrophic hormones, including $\mathrm{PTH}, 25-\mathrm{OH}$ vitamin $\mathrm{D}_{2}$ and $1,25-(\mathrm{OH})_{2}$ vitamin $\mathrm{D}_{3}$. The N3 group had significantly higher concentrations of serum systemic calcitrophic hormones than the $\mathrm{N} 6+\mathrm{N} 3$ control group (Table 3).

\section{Serum bone biomarkers}

There were no differences in serum bone turnover biomarkers (BALP, PYD) between the N6+N3 and baseline group (Table 3). The rats fed the N6 diet had a higher serum PYD concentration but the same serum BALP activity compared with those in the baseline group. Rats fed the N3 diet showed significantly higher BALP activity but no difference in serum PYD compared with baseline. When compared with the N6 + N3 control group, the N6 group had a higher PYD concentration, whereas the $\mathrm{N} 3$ group had higher BALP activity.

\section{Serum and urinary $\mathrm{Ca}$ and phosphate}

Compared to the baseline group: all dietary treatment groups had higher urinary Pi values; the N6 and N3 groups had a higher serum $\mathrm{Pi}$; the N6 + N3 and N6 groups had a higher urinary Ca (Table 3). Compared with the N6 + N3 control group, the N6 and N3 groups had a significantly higher level of serum Pi. The N3 group had higher serum Pi but lower urinary $\mathrm{Ca}$ and Pi compared with the $\mathrm{N} 6+\mathrm{N} 3$ control group.

\section{Bone mineral density}

There were no differences in the DEXA total area of the femoral bone region between the baseline group and the dietary treatment groups (Table 4). Both the dietary treatment groups, however, had significantly lower values for whole-femur BMD (as measured by DEXA), trabecular and cortical + subcortical bone densities (as measured by peripheral quantitative computerized tomography), compared with the baseline group. There was no difference in $\mathrm{BMC}$ between the baseline and the $\mathrm{N} 3$ groups, however; both the N6 + N3 control and N6 groups had a lower BMC compared with baseline. Moreover, rats fed the N3 diet had significantly higher BMC and cortical + subcortical bone density values than those fed the control N6 $+\mathrm{N} 3$ diet. There was no difference in any aspect of BMD between the $\mathrm{N} 6+\mathrm{N} 3$ control group and the N6 group. 
Table 3. Effect of different lipid treatments on local factors, systemic hormones and bone turnover biomarkers in gonad-intact middle-aged male rats

(Mean values with their standard errors, $n 7$ )

\begin{tabular}{|c|c|c|c|c|c|c|c|c|}
\hline \multirow[b]{3}{*}{ Experimental groups } & & & \multicolumn{6}{|c|}{ Dietary treatment $†$} \\
\hline & \multicolumn{2}{|c|}{ Baseline } & \multicolumn{2}{|c|}{$\mathrm{N} 6+\mathrm{N} 3$} & \multicolumn{2}{|c|}{ N6 } & \multicolumn{2}{|c|}{ N3 } \\
\hline & Mean & SEM & Mean & SEM & Mean & SEM & Mean & SEM \\
\hline \multicolumn{9}{|l|}{ Local factor (bone organ culture) } \\
\hline $\mathrm{PGE}_{2}$ (ng/g bone dry weight) & $41 \cdot 7$ & $5 \cdot 4$ & $8 \cdot 1$ & $1 \cdot 7^{\star \mathrm{b}}$ & $27 \cdot 9$ & $5 \cdot 6^{\mathrm{a}}$ & $7 \cdot 3$ & $3 \cdot 4^{\star b}$ \\
\hline $\mathrm{NO}$ (nmol/g bone dry weight) & $30 \cdot 0$ & 4.8 & $24 \cdot 8$ & $3 \cdot 7^{\mathrm{a}}$ & $23 \cdot 2$ & $4 \cdot 1^{\mathrm{a}}$ & $13 \cdot 2$ & $2 \cdot 6^{\star b}$ \\
\hline \multicolumn{9}{|l|}{ Systemic hormones (serum) } \\
\hline IGF-I (ng/ml) & 736 & 39 & 658 & $40^{\mathrm{b} *}$ & 727 & $47^{\mathrm{b} *}$ & 938 & $69^{a *}$ \\
\hline PTH (pg/ml) & 279 & 49 & 1024 & $55^{\mathrm{b} *}$ & 848 & $85^{\mathrm{b} *}$ & 1334 & $45^{\mathrm{a} *}$ \\
\hline $25-(\mathrm{OH})$ vitamin $\mathrm{D}_{2}(\mathrm{pg} / \mathrm{ml})$ & $27 \cdot 8$ & 0.6 & $19 \cdot 2$ & $0 \cdot 2^{b *}$ & $18 \cdot 7$ & $0.4^{\mathrm{b} *}$ & 31.5 & $0.9^{a *}$ \\
\hline $1,25-(\mathrm{OH})_{2}$ vitamin $\mathrm{D}_{3}(\mathrm{pg} / \mathrm{ml})$ & $28 \cdot 8$ & $2 \cdot 3$ & $127 \cdot 9$ & $9 \cdot 3^{\mathrm{b} *}$ & $134 \cdot 8$ & $8 \cdot 9^{\mathrm{a}, \mathrm{b} *}$ & $176 \cdot 0$ & $19 \cdot 5^{\mathrm{a} *}$ \\
\hline \multicolumn{9}{|l|}{ Serum bone turnover biomarker } \\
\hline BALP (units/l) & $67 \cdot 1$ & 3.4 & $69 \cdot 8$ & $5 \cdot 4^{\mathrm{b}}$ & $74 \cdot 2$ & $6 \cdot 1^{\mathrm{b}}$ & $122 \cdot 8$ & $6 \cdot 2^{a *}$ \\
\hline PYD (nmol/l) & 4.6 & 0.2 & $5 \cdot 1$ & $0.7^{b}$ & $8 \cdot 3$ & $1 \cdot 1^{a *}$ & $5 \cdot 1$ & $0.5^{\mathrm{b}}$ \\
\hline \multicolumn{9}{|l|}{ Others } \\
\hline Serum Ca (mg/dl) & 8.5 & 0.03 & $9 \cdot 0$ & $0.07^{\star}$ & $9 \cdot 1$ & $0.05^{\star}$ & $9 \cdot 1$ & $0.07^{\star}$ \\
\hline Serum $\mathrm{Pi}(\mathrm{mg} / \mathrm{dl})$ & 4.7 & 0.3 & $5 \cdot 3$ & $0.1^{\mathrm{b}}$ & 6.5 & $0.3^{\mathrm{a} *}$ & $7 \cdot 3$ & $0 \cdot 2^{a *}$ \\
\hline Urinary Ca (mg/mg creatinine) & 0.08 & 0.003 & 0.13 & $0.013^{a *}$ & 0.13 & $0.014^{a *}$ & 0.07 & $0.005^{b}$ \\
\hline Urinary $\mathrm{Pi}$ (mg/mg creatinine) & 0.06 & 0.01 & 0.84 & $0.03^{a *}$ & 0.84 & $0.03^{a *}$ & 0.36 & $0.02^{b *}$ \\
\hline
\end{tabular}

$\mathrm{N} 6+\mathrm{N} 3$, safflower oil + menhaden oil diet; N6, safflower oil diet; N3, menhaden oil diet; PGE 2 , prostaglandin $E_{2}$; IGF-I, insulin-like growth factor-I; PTH, parathyroid hormone; BALP, bone-specific alkaline phosphatase; PYD, pyridinoline; $\mathrm{Pi}$, inorganic phosphate.

${ }^{a, b}$ Mean values within a row with unlike superscript letters differ significantly among three dietary treatments by one-way ANOVA followed by Tukey's test $(P<0.05)$.

* Mean values within a row indicated the difference between baseline group and dietary treatment groups by Student's $t$ test $(P<0.05)$.

†For details of diets, see Table 1.

\section{Discussion}

In the present investigation, a model of gonad-intact, middle-aged male rats was successfully used to study the relationships between dietary PUFA treatment and bone metabolism associated with ageing-induced bone loss. Compared with the 12-month-old baseline group, all dietary treatment groups fed the high-fat diets for 20 weeks had lower values for femur BMC $(15 \cdot 3,13.6$ and $5.7 \%$ for the N6, control N6 $+\mathrm{N} 3$ and N3 groups, respectively). This decrease could be due to ageing and/or the high fat content of the diets. The ageing effect on BMC has been reported by Wang et al. (2001): gonad-intact 17-month-old Sprague-Dawley male rats had a lower value for femur neck BMC (5\%) than 12-month-old rats.

For the current study, all rats in the baseline and dietary treatment groups were purchased from the same vendor at the same time. After 20 weeks, all rats were of the same age but had been fed diets with different fats. Our results showed that: (1) bone fatty acid composition in the different groups reflected the effects of dietary treatments, as reported in previous studies ( $\mathrm{Li}$ et al. 1999; Watkins et al. 2000, 2003), with results significantly different from the baseline; (2) there was no difference in the amount of food consumption between the three dietary groups; (3) there were significant differences in bone parameters in

Table 4. Effect of different lipid treatments on bone mineral density in gonad-intact, middle-aged male rats (Mean values with their standard errors, $n 7$ )

\begin{tabular}{|c|c|c|c|c|c|c|c|c|}
\hline \multirow{2}{*}{ Experimental groups } & & & \multicolumn{6}{|c|}{ Dietary treatment $†$} \\
\hline & \multicolumn{2}{|c|}{ Baseline } & \multicolumn{2}{|c|}{$\mathrm{N} 6+\mathrm{N} 3$} & \multicolumn{2}{|c|}{ N6 } & \multicolumn{2}{|c|}{ N3 } \\
\hline \multicolumn{9}{|l|}{ DEXA } \\
\hline $\mathrm{BMC}(\mathrm{g})$ & 0.59 & 0.01 & 0.51 & $0.01^{\mathrm{b} *}$ & 0.51 & $0.01^{\mathrm{b} *}$ & 0.56 & $0.02^{a}$ \\
\hline Total area $\left(\mathrm{cm}^{2}\right)$ & $2 \cdot 30$ & 0.03 & $2 \cdot 47$ & 0.06 & $2 \cdot 32$ & 0.05 & $2 \cdot 36$ & 0.04 \\
\hline \multicolumn{9}{|l|}{ pQCT } \\
\hline Total density $\left(\mathrm{mg} / \mathrm{cm}^{3}\right)$ & 776 & 13 & 610 & $13^{*}$ & 621 & $21^{*}$ & 653 & $5^{\star}$ \\
\hline Trabecular bone density $\left(\mathrm{mg} / \mathrm{cm}^{3}\right)$ & 487 & 18 & 241 & $9^{*}$ & 259 & $16^{*}$ & 259 & $10^{*}$ \\
\hline $\mathrm{C}+\mathrm{S}$ density $\left(\mathrm{mg} / \mathrm{cm}^{3}\right)$ & 1019 & 11 & 919 & $16^{\mathrm{b} *}$ & 920 & $23^{\mathrm{b} *}$ & 968 & $12^{\mathrm{a} *}$ \\
\hline
\end{tabular}

N6 + N3, safflower oil + menhaden oil diet; N6, safflower oil diet; N3, menhaden oil diet; DEXA, dual-energy X-ray absorptiometry; BMC, bone mineral content; BMD, bone mineral density; pQCT, peripheral quantitative computerized tomography; C + S, cortical + subcortical;

a,b Mean values within a row with unlike superscript letters differed significantly between the three dietary treatments by one-way ANOVA followed by Tukey's test $(P<0.05)$.

* Mean values within a row indicated the difference between the baseline group and dietary treatment groups by Student's $t$ test $(P<0.05)$.

†For details of diets, see Table 1. 
those fed with N6 or N3 diets compared with the control N6 + N3 diet. Therefore, the relative difference in bone loss should be mainly due to the variation in the dietary fat source. The fatty acid and methyl ester analysis of bone shown in Table 2 indicates that rats fed the N3 diet had significantly higher (threefold) amounts of $n-3$ PUFA and a reduction in $n-6$ PFUA of $50 \%$ (in linoleate of $64 \%$ ) compared with those fed the N6 + N3 diet.

Our data showed that BMC in the N3 group was not significantly different from that in the baseline group, but was higher than that in the control N6 $+\mathrm{N} 3$ and N6 groups, suggesting that diets rich in LC $n-3$ PUFA resulted in less bone loss in middle-aged male rats during bone remodelling. Such a bone-mass conservation by LC $n-3$ PUFA agrees with that reported for ovariectomy-induced osteopenia in female rats (Watkins et al. 2003, 2005) and mice (Sun et al. 2003).

It was noted that the safflower oil used in this study contained a small amount of cholecalciferol (vitamin $\mathrm{D}_{3} ; 5 \mu \mathrm{g}$ vitamin $\mathrm{D}_{3}$ per $100 \mathrm{~g}$ oil), whereas menhaden oil contained $10 \mu \mathrm{g}$ vitamin $\mathrm{D}_{3}$ per $100 \mathrm{~g}$ oil (Staffas \& Nyman, 2003). In addition to the vitamin $\mathrm{D}_{3}$ present in the menhaden oil, $25 \mu \mathrm{g}$ cholecalciferol per kilogram of diet was added as a supplement to all dietary treatments. As a result, the amounts of cholecalciferol in the $\mathrm{N} 3, \mathrm{~N} 6+\mathrm{N} 3$ and N6 diets were $44.5,36.5$ and $35 \mu \mathrm{g} / \mathrm{kg}$ diet, respectively. Because the amount of food consumption was the same in each group, the total intake of cholecalciferol in the N3 group was $27 \%$ higher than that in the N6 group.

Higher values for PTH $(57 \%), 25-\mathrm{OH}$ vitamin $\mathrm{D}_{2}(68 \%)$ and $1,25-(\mathrm{OH})_{2}$ vitamin $\mathrm{D}_{3}(31 \%)$ in the $\mathrm{N} 3$ group could be due to a different dietary fat and/or vitamin $\mathrm{D}_{3}$ level in the menhaden oil. Such a small increase in vitamin $\mathrm{D}_{3}$ in the N3 diet might, at least partially, have favoured bone remodelling during ageing. Treatments with vitamin $\mathrm{D}_{3}$ and vitamin $\mathrm{D}$ analogues have been demonstrated to reduce bone loss in ovariectomized female rats (Shiraishi et al. 1999) and aged male rats (Li et al. 2004). Compared with the rats fed safflower oil in the N6 diet (almost devoid of LC $n$-3 PUFA), the N3 diet (rich in LC $n-3$ PUFA) favoured bone conservation in rats through a reduction in local catabolic factors such as $\mathrm{PGE}_{2}$ (Spencer et al. 1991, Li et al. 1999; Watkins et al. 2000) and NO (MacIntyre et al. 1991; Ralston et al. 1995; van't Hof et al. 2000; Gyurko et al. 2005), and increased circulating anabolic factors such as IGF-I (Spencer et al. 1991; Ammann et al. 1996) and BALP (Watkins et al. 2000), as evidenced by favourable changes in terms of lowered serum PYD (Kelly et al. 2003; Watkins et al. 2003) and urinary Ca (Buck et al. 1991; Claassen et al. 1995) levels. In addition, a recent study reported by Weatherill et al. (2005) provided some evidence that dietary LC $n-3$ and $n-6$ PUFA may also modulate bone formation and resorption via regulating $\mathrm{T}$-cell function and the production of cytokines such as IL-1, IL- 6 and transforming necrosis factor $\alpha$. Future studies are needed to evaluate such possible mechanisms.

The dietary $n-6: n-3$ PUFA ratio plays an important role in bone metabolism (Watkins et al. 2000; Weiler \& Kruger, 2004; Weiss et al. 2005). Although our results showed no difference in the BALP and BMD data between the N6 + N3 and N6 groups, in the present study supplementation of the control N6 + N3 diet with LC $n-3$ PUFA significantly decreased the bone ex vivo $\mathrm{PGE}_{2}$ production and serum PYD concentration of rats compared with those in the N6 diet (almost devoid of LC $n-3$ PUFA), indicating a lower resorption rate in rats fed the $\mathrm{N} 6+\mathrm{N} 3$ diet.
Despite the differences between gonad-intact, middle-aged male rats and middle-aged men in terms of the impact of fishoil supplementation on bone metabolism, we believe that our study presents a critical first step towards assessing the effects of high fish oil consumption on skeletal metabolism in middleaged men. Our data have demonstrated that a diet rich in LC $n$-3 PUFA, antagonistic to arachidonic acid in terms of prostanoid action, mitigated ageing-induced bone loss in intact, middle-aged male rats during skeletal remodelling. This suggests that dietary supplementation rich in LC $n-3$ PUFA might contribute to the maintenance of a healthy skeletal system in middle-aged men. Future investigations should test the potential for a protective effect of a high LC $n-3$ PUFA diet on bone structure and mechanical properties to further our understanding of the role of lipid nutrition in skeletal health and the prevention of pathological bone loss (osteoporosis) during male ageing.

\section{Acknowledgements}

This investigation was supported by a Texas Tech University grant and the Center for Enhancing Food to Protect Health, Purdue University, West Lafayette, IN, USA. The authors thank Ali Raja for his help with animal care.

\section{References}

Ammann P, Rizzoli R, Meyer JM \& Bonjour JP (1996) Bone density and shape as determinants of bone strength in IGF-I and/or pamidronatetreated ovariectomized rats. Osteoporos Int 6, 219-227.

Bhattacharya A, Rahman MM, Sun D, Lawrence R, Mejia W, McCarter R, O'Shea M \& Fernandes G (2005) The combination of dietary conjugated linoleic acid and treadmill exercise lowers gain in body fat mass and enhances lean body mass in high fat-fed male Balb/C mice. J Nutr 135, 1124-1130.

Buck AC, Davis RL \& Harrison TJ (1991) The protective role of eicospentaenoic acid (EPA) in the pathogenesis of nephrolithiasis. $J$ Urol 146, 188-194.

Center JR, Nguyen TV, Schneider D, Sambrock PN \& Eisman JA (1999) Mortality after all major types of osteoporotic fracture and observational study. Lancet 353, 878-882.

Choi JS, Jung MH, Park HS \& Song J (2004) Effect of conjugated linoleic acid isomers on insulin resistance and mRNA levels of genes regulating energy metabolism in high-fat-fed rats. Nutrition 20, 1008-1017.

Claassen N, Potgieter HC, Seppa M, Vermaak WJ, Coetzer H, Van Papendorp DH \& Kruger MC (1995) Supplemented gamma-linolenic acid and eicosapentaenoic acid influence bone status in young male rats: effects on free urinary collagen crosslinks, total urinary hydroxyproline, and bone calcium content. Bone 16, Suppl., 385S-392S.

Gyurko R, Shoji H, Battaglino RA, Boustany G, Gibson FC 3rd, Genco CA, Stashenko P \& Van Dyke TE (2005) Inducible nitric oxide synthase mediates bone development and $P$. gingivalis-induced alveolar bone loss. Bone 36, 472-479.

Hoffmann WE, Everds N, Pignatello M \& Solter PF (1994) Automated and semiautomated analysis of rat alkaline phosphatase isoenzymes. Toxicol Pathol 22, 633-638.

Hou JC-H, Zernicke RF \& Barnard RJ (1990) High-fat sucrose diet effects on femoral neck geometry and biomechanics. Clin Biomech 5, $162-168$.

Kelly O, Cusach S, Jewell C \& Cashman KD (2003) The effect of polyunsaturated fatty acids, including conjugated linoleic acid, on calcium absorption and bone metabolism and composition in young growing rats. Br J Nutr 90, 743-750.

Kopelman PG (2000) Obesity as a medical problem. Nature 404, 635-643. 
Kruger MC, Claassen N, Potgieter HC, Coetzer H \& de Winer R (1996) Essential fatty acid supplementation and calcium retention in the ovariectomised rat. Osteoporos Int 6, 101.

Kruger MC, Coetzer H, de Winter R, Gericke G \& van Papendorp DH (1998) Calcium, gamma-linolenic acid and eicosapentaenoic acid supplementation in senile osteoporosis. Aging (Milano) 10(5), 385-394.

Li M, Healy DR, Li Y, Simmons HA, Su M, Jee WSS, Shen VW \& Thompson DD (2004) Alfacalcidol prevents age-related bone loss and causes an atypical pattern of bone formation in aged male rats. $J$ Musculoskel Neuron Interact 4, 22-32.

Li Y, Seifert MF, Ney DM, Grahn M, Grant AL, Allen KG \& Watkins BA (1999) Dietary conjugated linoleic acids alter serum IGF-I and IGF binding protein concentrations and reduce bone formation in rats fed (n-6) or (n-3) fatty acids. J Bone Miner Res 14, 1153-1162.

MacIntyre I, Zaidi M, Alam AS, Datta HK, Moonga BS, Lidbury PS, Hecker M \& Vane JR (1991) Osteoclastic inhibition: an action of nitric oxide not mediated by cyclic GMP. Proc Natl Acad Sci USA 88, 2936-2940.

Mundy GR (2003) Cytokine and growth factors in the regulation of bone remodeling. J Bone Miner Res 8, Suppl. 2, S505-S510.

Nadon NL (2004) Maintaining aged rodents for biogerontology research. Lab Animal 33, 36-41.

Nyman A (2003) Determination of cholecalciferol (vitamin $D_{3}$ ) in selected foods by liquid chromatography: NMKL collaborative study. J AOAC Int 86, 400-406.

Raisz LG \& Rodan GA (2003) Pathogenesis of osteoporosis. Endocrinol Metab Clin North Am 32, 15-24.

Ralston SH, Ho L-P, Helfrich MH, Grabowski PS, Johnston PW \& Benjamin N (1995) Nitric oxide: a cytokin-induced regulator of bone resorption. J Bone Miner Res 10, 1040-1049.

Rizek RL, Welsh SO, Marston RM \& Jackson EM (1983) Dietary fats and health. In Levels and sources of fat in the US food supply and in diets of individuals, pp. 13-43 [EG Perkins and WJ Visek, editors]. Champaign, IL: American Oil Chemists' Society.

Rowe JW \& Kahn RL (1987) Human aging: usual and successful. Science 237, 143-149.

Sakaguchi K, Morita I \& Murota S (1994) Eicosapentaenoic acid inhibits bone loss due to ovariectomy in rats. Prostaglandins Leukot Essent Fatty Acids 50, 81-84.

Schlemmer CK, Coetzer H, Claassen N \& Kruger MC (1999) Oestrogen and essential fatty acid supplementation corrects bone loss due to ovariectomy in the female Sprague Dawley rat. Prostaglandins Leukot Essent Fatty Acids 61, 381-390.

Shen CL, Dunn DM, Henry JH, Li Y \& Watkins BA (2004) Decreased production of inflammatory mediators in human osteoarthritic chondrocytes by conjugated linoleic acids. Lipids 39, 161-166.
Shiraishi A, Higashi S, Ohkawa H, Kubodera N, Hirasawa T, Ezawa I, Ikeda K \& Ogata E (1999) The advantage of alfacalcidol over vitamin $\mathrm{D}$ in the treatment of osteoporosis. Calcif Tissue Int $\mathbf{6 5}$, 311-316.

Simopoulos AP, Leaf A \& Salem N Jr (1999) Essentiallity of and recommended dietary intakes for omega- 6 and omega- 3 fatty acids. Ann Nutr Metab 43, 127-130.

Spencer EM, Lin CC, Si ECC \& Howard GA (1991) In vivo action of insulin-like growth factor-I on bone formation and resorption in rats. Bone 12, 21-26.

Sun D, Krishnan A, Zaman K, Lawrence R, Bhattacharya A \& Fernandes G (2003) Dietary (n-3) fatty acids decrease osteoclastogenesis and loss of bone mass in ovariectomized mice. J Bone Miner Res 7, 18, $1206-1216$.

van't Hof RJ, Armour KJ, Smith LM, Wei XQ, Liew FY \& Ralston SH (2000) Requirement of the inducible nitric oxide synthase pathway for IL-1 induced osteoclastic bone resorption. Proc Natl Acad Sci 97, 7993-7998.

Vaskonen T, Laakso J, Mervaala E, Sievi E \& Karppanen H (1996) Interrelationships between salt and fish oil in stroke-prone spontaneously hypertensive rat. Blood Press 5, 178-189.

Wang L, Banu J, McMahan CA \& Kalu DN (2001) Male rodent model of age-related bone loss in men. Bone 29, 141-148.

Watkins BA, Li Y, Allen KGD, Hoffmann WE \& Seifert MF (2000) Dietary ratio of $(n-6) /(n-3)$ polyunsaturated fatty acids alters the fatty acid composition of bone compartments and biomarkers of bone formation in rats. $J$ Nutr 130, 2274-2284.

Watkins BA, Li Y, Lippman HE \& Feng S (2003) Modulatory effect of omega-3 polyunsaturated fatty acids on osteoblast function and bone metabolism. Prostaglandin Leukot Essent Fatty Acids 68, 387-398.

Watkins BA, Reinwald S, Li Y \& Seifert MF (2005) Protective actions of soy isoflavones and n-3 PUFAs on bone mass in ovariectomized rats. $J$ Nutr Biochem 16, 479-488.

Watkins BA, Shen CL, Allen KG \& Seifert MF (1996) Dietary (n-3) and (n-6) polyunsaturates and acetylsalicylic acid alter ex vivo $\mathrm{PGE}_{2}$ biosynthesis, tissue IGF-I levels, and bone morphometry in chicks. J Bone Miner Res 11, 1321-1332.

Weatherill AR, Lee JY, Zhao L, Lemay DG, Youn HS \& Hwang DH (2005) Saturated and polyunsaturated fatty acids reciprocally modulate dendritic cell functions mediated through TLR4. J Immunol 174, 5390-5397.

Weiler HA \& Kruger MC (2004) Polyunsaturated fatty acids and one mass. Am J Clin Nutr 80, 1085-1086.

Weiss LA, Barrett-Connor E \& van Mühlen D (2005) Ratio of n-6 to n-3 fatty acids and bone mineral density in older adults: the Rancho Bernardo Study. Am J Clin Nutr 81, 934-938. 